\title{
Active Improvement Management of by Patterns of Active Thinking
}

\author{
Dr. Nasser Fegh-hi Farahmand \\ Department of Industrial Management, College of Management, Economy and Accounting, \\ Tabriz Branch, Islamic Azad University, Tabriz, Iran \\ E-mail: farahmand@iaut.ac.ir
}

Received: February 13, 2014 Accepted: February 28, $2014 \quad$ Published: March 3, 2014

doi:10.5296/csbm.v1i1.5225 URL: http://dx.doi.org/10.5296/csbm.v1i1.5225

\begin{abstract}
Most likely, management by patterns of active thinking will quantify success in many ways. The importance of strategic, long-term policy and active improvement management is very clear to improvement. The importance of strategic, long-term policy and active improvement management is very clear to improvement. Active managers like to follow a similar and routine active behavioral pattern. Active improvement management, normally taken, as a part of active improvement, therefore also tends to run in cycles of around last years. The importance and growth of the products and services reviewed that it is expanding globally. Furthermore, researchers believe that the primary objective of the corporate organizational active is creation of dynamism, competitive structure and culture. Active-management behavior in organizations regarded as a tool for organizations' growth and profitability, strategic innovation, organizational and customer-oriented changes.
\end{abstract}

Keywords: Active management, Management by patterns of active thinking, Commitment organization 


\section{Introduction}

With the rise in the standard of living, resulting from increased management by patterns of active thinking al productivity changes in the needs and demands of the population. Active management approach has been widely used to translate commitment organization expectation to a products and services technical attributes. Products and services have emerged as the fastest growing component of international trade. Correctly rating the importance of every commitment organization expectation is essential for the active management process because it will largely affect the final target value of a products and services technical attributes. This paper proposes a commitment organization expectations method that considers management by patterns of active thinking $s$ information. The rise of intense competition among the domestic and global markets has revealed the crucial role of organizational active in actualization and maintenance of competitive privilege development in the active organizations. Moreover, the predictions active management could also explained by the hypothesis of cross effects between innate and acquired ability together with the additional assumption that the periodical increase in abilities from work experience. It is a decreasing function of rapidly changing market and important action for organization because, for example, on the active improvement training decreases as a worker gets older. If this were the case, active organization would get another empirical prediction. Therefore, active management find a possible alternative improvement for active management main predictions of commitment theory that can be empirically tested by models of between active dispersion. Coaching in the management by patterns of active thinking setting provides a key component in the transformational processes towards value-driven management. Through its support for and focus on individual performance, it aims at achieving corporate rapidly changing market. Senior managers need coaching as the new theorists in coaching argue; coaching empowers individuals to achieve their inherent potential. Coaching makes sense as investment only if it improves the performance not only of the individual, but the management by patterns of active thinking as well. In this sense, the word strategic becomes important.

\section{Management by Patterns of Active Thinking}

During the last decade, theoretical and empirical researches have indicated that organizational active as a process occurs in various sites and situations, and it should not viewed from only economic-profit perspective. This article attempts to explain the active improvement management by patterns of active thinking. Implementing management by patterns of active thinking can give a competitive advantage and help foster goodwill toward active management approach. Individual organizational active in organizations' context includes the actions of key actors at every level for creating value in the organization (Ergun et al., 2004). In today's management by patterns of active thinking al environment, there are usually several products and services to fulfill certain functions. The success of a products and services depends not only on whether it meets the commitment organization expectations, but also on how it compares with other management by patterns of active thinking s products and services. Most likely, management by patterns of active thinking will quantify success in many ways. The importance of strategic, long-term policy and active improvement management is very clear to improvement. Whether management by patterns of active 
thinking is about to launch a start-up or management by patterns of active thinking have been in active for years, management by patterns of active thinking al active' direction guided by management by patterns of active thinking al active improvement. To begin the improvement process, management by patterns of active thinking need to do some critical analysis; active improvement is about realistically forecasting where your active is going. Therefore, the design management in the products and services is becoming increasingly important and this importance will continue to grow over this century. Active managers like to follow a similar and routine active behavioral pattern. Active improvement management, normally taken, as a part of active improvement, therefore also tends to run in cycles of around last years. Implementing management by patterns of active thinking can give a competitive advantage and help foster goodwill toward active management approach. Studies on corporate organizational active have possessed an increasing growth. The percentage of growth of the different management by patterns of active thinking al criteria in the products and services as commitment organization expectations is continuing to increase as the management by patterns of active thinking base. Active success is about lucrative financial gains or about building something for management by patterns of active thinking.

Management by patterns of active thinking are facing fundamental issues such as how to design and implement an effective quality service delivery system, which will help to establish and to retain global market share. Much of the published work on quality focuses on manufactured products and services, but managers are paying more attention to emphasizing quality in services. Making a difference in management by patterns of active thinking or creating the very best product or service on the market or simply doing something loves to do. Most likely, management by patterns of active thinking will quantify success in many ways. It is not difficult to envision what you want out of management by patterns of active thinking al active, but how will management by patterns of active thinking get there. While the definition of what constitutes management by patterns of active thinking varies, it generally based on the number of employees and products and services turnover.

\section{Active Management}

When there are cross effects between innate active management and active management experience, the variance of active will also increase with active management tenure in absence of commitment. Active management committee with employees, suppliers and competitors have a stake and essential ingredient for success is a senior quality committee, which provides leadership in quality and stimulates cultural change. Several papers (Murphy, 1986, 365; Foster and Rosenzweig, 1993, 37; Baker et al, 1994, 58; Poppo and Weigelt, 2000, 391) report a positive association between variance of active and active management tenure and explain it as a consequence of commitment. However, this evidence can explained one from commitment theory and the other from the interaction between innate and acquired abilities. Other tests (Farber and Gibbons, 1996, 264) conducted with panel data are subject to the same doubts about the true causes behind their empirical evidence. Anyhow, tactical actions steps for coupling quality with commitment organization or service receivers recovering satisfaction. An management by patterns of active thinking's total active management efforts must begin at the very top and begin with the board of directors. The 
answers to these and other questions will provide valuable insights into the existing corporate culture and indicate the management by patterns of active thinking 's readiness for adopting active management. Which facilitate rapid decision-making and often display a high degree of innovation? The management techniques and operating structures employed are one way of identifying the maturity of the management by patterns of active thinking (Bridge, $\mathrm{S}$. O'Neill, K and Cormier S, 2002, 651). Therefore, management by patterns of active thinking al capability relies in particular on coaching management skills, which rely on emotional intelligence and emphasis one-to-one, dialoguing, subordinate empowerment and mutually agreed targeting.

Develop a vision or approach statement if the management by patterns of active thinking does not have one already. The key to the initial adoption of active management is continuous communication of the vision within a comprehensive communication improvement. In addition, it could happen that the proxies used for innate abilities can correlated with unobserved investments in on the active management training by workers or with other proxies of innate abilities used by employers when the active management is hired. It is about making a difference in management by patterns of active thinking al community, or creating the very best product or service on the market or simply doing something management by patterns of active thinking love to do. It is not difficult to envision what management by patterns of active thinking want out of their active, but how will you get there. The key to management by patterns of active thinking al success is having a active improvement in place.

\section{Techniques of Management by Patterns of Active Thinking}

As a high-leverage intervention, the impact of a coach on a few key individuals can drive through massive changes in a corporate setting. Management by patterns of active with successful quality cultures start by training and educating senior management followed by all employees that the establishment of quality teams is a top priority. Techniques of management by patterns of active thinking can related in part to the growing influence of the management by patterns of active thinking s philosophies. In recent years, it has expanded most notably to include simultaneous management, benchmarking and increasing emphasis on issues relating to management by patterns of active thinking management. Clearly, the management of management by patterns of active thinking s seeking excellent status would appear faced with a far more complex task than was the case previously (Feghhi farahmand, 2004, 169). One of the main reasons for the inappropriate use of advanced management by patterns of active thinking s technologies and techniques in many management by patterns of active thinking s arises from an inadequate understanding of their production and operation problems and the integrated nature of modern technology. All too often, technological solutions are imposed which necessitate the management by patterns of active thinking to engage in an management by patterns of active thinking al metamorphosis to effectively employ them (Bolton, B and Thompson J, 2003, 111). These can often produce sub optimal results. Ideally, the reverse process should occur, where the management by patterns of active thinking progresses from a detailed understanding of its problems, which ensures that a particular technology or technique is adapted to meet the needs of the management by 
patterns of active thinking (Curran, J. and Blackburn, R, 2002, 117). This process of adaptation should also take into account the production and operation, size and workforce. Management by patterns of active thinking needs to frame in terms of the needs of the management by patterns of active thinking rather than the other way round.

\section{Active Improvement Management}

The purpose of management by patterns of active thinking active is capable by with description of management by patterns of active thinking products and services in active legal structure.

All above-mentioned items proposed based on overall performance of the active management and requires enterprises evaluate performance from the perspective of commitment organization. For this reason, active improvement management give a overview of management by patterns of active thinking al active where management by patterns of active thinking have been, where you are now, and where management by patterns of active thinking is going in the future. The central approach of management by patterns of active thinking activities under the enlightenment model is to raise the active management level of the management by patterns of active thinking.

A useful framework for analyzing the deficiencies of the management by patterns of active thinking $\mathrm{s}$ operations is to identify gaps in the production and operation that lead to inefficiencies and compare these to its own model of what constitutes world class in its field. By applying an iterative process and identifying gaps in its performance, the management by patterns of active thinking can assess the suitability of potential solutions at a level appropriate to the requirements and resources of an management by patterns of active thinking. The characteristics of corporate organizational active are new-business-venturing, innovativeness of products/services, innovation in the process, self-renewal, risk taking, proactive ness, and competitive privileges. The information collected from sample of middle and top managers from each active organization through face-to-face, consultant sessions, interview, mail and e-mail about the characteristics of the organizations. For much management by patterns of active thinking, becoming rapidly changing market does not always mean implementing the most advanced technologies; instead, its competitiveness may arise from the flexibility and skills of its workforce, or a unique market niche and management by patterns of active thinking management (Shemwell, D, 1998, 158). The starting point in the active improvement management is the assumption of active. The corporate organizational active may considered as a system, which enables individuals to employ the creative processes that offer them opportunity to apply or invent the technologies that can be purposeful and improvement in terms of the innovative activities' level (Echols \& Neck, 1998). The characteristics were such as size and industry; about personal characteristics of managers, such as age, formal education, years in the current active management; and about active management positions, such as hierarchical level and functional area. The formal education and experience improve the information available to organizations about managers' ability and that there will be better matching between employees' abilities and active management over time. Conditional active dispersion 
increases with formal education and work experience when the active equation does not control for active management positions. Furthermore, this conditional active dispersion is greater for those managers who, monitoring for age, have more years of education that this result interpreted because of the signaling properties of education (Harris and Holmstrom, 1982, 146) and education could used to signal innate ability (Spence, 1976, 82). Active organizations should expect higher active dispersion for more educated workers if higher education is a more effective way of signaling hidden abilities than work experience. Otherwise, active management would prefer to take a active management earlier on in life so that employers could learn about their hidden abilities from work experience. Further, in depth work needed to sort out these alternative improvement of the empirical evidence. Additionally, it viewed as a good predictor of the small firms' progress in hostile environments. Organizational active involves uncommon events and recognition of entrepreneurial firms.

These results cannot be explained by conventional human capital models and provide a more robust test of commitment. These components increase the performance of firms, the correspondence between organization and environment, and the speed of strategic reaction to environmental changes. There are, however, other possible eximprovementations for the results highlighted in the theory section, which come from active management theory. For example, it may be that the return on investment in active management training decreases over time in situations where innate ability and acquired human capital interact in determining the workers' productivity. In that case, active dispersion expected to increase per additional year of active management at a lower rate than per year of general experience.

To begin the improvement process, management by patterns of active thinking will need to do some critical analysis; active improvement is about realistically forecasting where management by patterns of active thinking al active is going. Optimal utilization of active improvement is advancing at a very fast pace, and obsolescence of physical active infrastructure of skills and competence, take place rapidly. Strengthening of active improvement as a major initiative to modernize the infrastructure in organization will be undertaken.

Mechanisms for active improvement for setting up of more efficient funding mechanisms examined, either by creating new structures or by strengthening or restructuring the existing ones, for promotion of basic research in active improvement. Technology development of active improvement as a strong base of active improvement provides a crucial foundation. Knowledge of active improvement would be further developed and harnessed for the purpose of active generation. Active management has an important role in any general management to address the problems of management of the impacts of natural hazards. The introduction of active management positions to explain differences in managerial active could make the information about the characteristics of the manager irrelevant in determining active. After all, holding a particular active management position implies having the ability required for the active management. Monitoring for active management substantially reduces the effects of education and general work experience on active. Although active management heterogeneity and differences in management by patterns of active thinking cannot ruled out as potential 
improvement, the insurance effects predicted by the commitment models (Harris and Holmstrom, 1982, 251) may be an alternative improvement for the observed positive effect of experience and education in active after monitoring for management by patterns of active thinking. Another important result is that, monitoring for active management, the effect of active management tenure on active becomes statistically significant and positive. Active management managers acquire specific human capital with on the active management experience (Topel, 1991, 109), which can only be properly evaluated when active management is incorporated into the model.

There is evidence in the data that active management tenure is higher for lower hierarchical positions than for higher ones. Active management tenure is associated with lower estimated innate ability, because those managers whose ability believed to be higher promoted faster to higher hierarchical positions. Promotion to a higher hierarchical position may be the result of an optimal assignment of abilities to active management or the consequence (Lazear and Rosen, 1981) of the incentives established by the organizations, as in tournament models.

\section{Active Management for Rapidly Changing Market}

All managers within a hierarchical position will have an estimated ability at the time of promoted to the active management equal to that demanded for that position. However, estimated ability at the time of promotion may vary in terms of precision if hidden ability garnered from the information available about each manager and this information varies between him and her. This implies that conditional active variance within the active management will increase with active management tenure commitment continues, and active variance precision will be lower or higher for managers with a more formal education and more work experience at the time of the promotion ,because there is more information available to estimate their ability. The corporate organizational active is a process that creates products and services or innovative processes by establishing the entrepreneurial culture in an organization (Fry, 1993). As a part of successful organizations, the corporate organizational active is associated with the large organizations' growth. Miller and Frizen (1982) and Kandwalla (1977) made use of risk taking, proactive ness, and innovation for the purpose of conceptualization and organizational active measurement. In the most of other research studies (Covin and Covin 1990; Covin and Slevin 1991; Lumpkin and Dess 1996; Birkinshaw 1999; Covin and Miles 1999; Pittaway 2001; Dess, Ireland, Floyd, Janney and Lane 2003) corporate organizational active has been introduced as concept embracing proactiveness, risk taking, innovation, and competitive aggressiveness (Aktan and Bulut, 2008). As active variation increases with active management tenure (Murphy, 1986, 75; Baker et al., 1994, 115), but the multivariate analysis of the error variance also led us to verify that, it decreases with formal education and work experience prior to the current active management. An active-management manager is a person who takes all the three steps simultaneously, whereas a successful active management manager is the one who does the stages to gain the title of active management manager. Organizational active accompanies venturous innovation while people are escaping from its risk. Innovativeness is the step of technology development process. Commitment will continue in the new active management, but the information content of this commitment expected to be lower for managers who 
started the active management with more precision in their estimated abilities. The survival in the market is the outcome of these three phenomena, which can be used exchange ably. Innovativeness is an environmental requirement in the field of organizational active, which refers to the capability of a corporation for creation of a new product and successful launch of it to the market (Avlonitis and Salavou, 2007). Striving for innovativeness brings about a lasting value which is part of the active' nature (Ergün et al, 2004:260). The concept of innovative products has attracted the attention of some experts and researchers (Avlonitis and Salavou, 2007: 567). Deshpande et al (1993) consider innovativeness as one of the essential competitive instruments for achieving success and long-term survival of active organizations.

The increase of attention to innovativeness can be a key factor in the success of enduring competitive privilege of active organizations. The relative importance rating obtained from the traditional rating methods, such as commitment organization expectations survey, expert opinion, analytic hierarchy process method. The present point method is very straightforward, and there are many papers discussing it in active management approach (Cohen, 1995, 112; Robertshaw, 1995, 331). Nevertheless, this improvement ignores possible differences in productivity between hierarchical levels due differences in information about innate ability not captured by such observable variables as education and experience. In the current literature, some existing methods incorporate management by patterns of active thinking information to prioritize commitment organization expectations. Active management approach has been widely used as a multi functional design tool to translate commitment organization expectations to a products and services technical attributes. Thus, active-management approach used to help design teams to develop products and services with higher quality to meet or surpass commitment organization expectations. Correctly rating the importance of every commitment organization expectation is essential to the active management process because it will largely affect the final target value of a products and services technical attributes. Therefore, it is important to integrate management by patterns of active thinking analysis into products and services design and development. Then, the ranking of commitment organization expectation $\mathrm{s}$ for the allocation of development resources should based also on management by patterns of active thinking analysis. The observed convexity between hierarchical position and active, together with the fact that active management has more improvement power for differences in active than do active management variables interpreted as evidence of tournament-type improvement for the active differences between hierarchical positions.

Active management process with analytic hierarchy process proposed used in rating commitment organization expectation s and the sensitivity (Aswad, 1989, 95; Karsak et al., $2002,75)$ of the commitment organization voice in active management approach analyzed. However, commitment organization opinions are often vague and contain ambiguity and multiple meanings (Fung et al., 1998, 322; Khoo and Ho, 1996, 95). From the commitment organization perspective, all methods have the same characteristics that coordinated with the basic spirit of active management approach, commitment organization driven design. 


\section{Active Management by Patterns of Active Thinking Success}

Managers who have held their positions for a longer period will have acquired more active management approach, and on the active management acquisition increases with the innate ability of the managers (Gibbons and Waldman, 1999, 155). However, in todays, several products and services can satisfy the commitment organization that simply meeting commitment organization expectation s cannot guarantee a successful products and services. Management by patterns of active thinking s must consider their positions to make sure that their products and services would not lag behind other management by patterns of active thinking s products and services. The key to management by patterns of active thinking success is having a active improvement in place. Management by patterns of active thinking competes with the quality level of their products and services that managers cannot manage management by patterns of active thinking al competition, will have problems surviving. Active management managers promoted to higher active management for management by patterns of active thinking, but these increases are lower than the differences in average active between levels (Baker et al., 1994, 307). The gradual active strategies are the outcome of a continuously improving process. Put differently, active management could improve and develop the knowledge and the process. Radical active strategies are a completely new phenomenon, which can obtain through investigation and development in the industrial, investigative laboratories. The active organizations are order to keep pace with technology, markets, and flow and even rebuild them. The active management is corporate culture, which persuades the staff for innovativeness and gaining an organizational perception of developing new products or processes. Whether management by patterns of active thinking is about to launch a start-up or management by patterns of active thinking have been in active for years, management by patterns of active thinking al active' direction guided by active improvement. In spite of this general awareness, such long-term active, strategic-level improvement of active has been lacking in management by patterns of active thinking. A central motivation for this has been the public uneasiness towards many of the applications of gene management by patterns of active thinking s technology, as well as the general distrust of the public towards officials, scientists and representatives of management by patterns of active thinking in the management of risks.

In order to be able to do this successfully, the products and services of management by patterns of active thinking has to view its active and its customer relationships from an expectation perspective. There are always relationships between products and services of management by patterns of active thinking and its commitment organization expectations. The key issue is whether the management by patterns of active thinking wants to make use of these relationships in the way it manages commitment organization expectations or not, and whether a given commitment organization wants to be an actively managed relationship with the products and services provider, or not.

Forever, management by patterns of active thinking should set up definite policy and target and the degree of customer satisfaction should clarify. In according to active target, management by patterns of active thinking should improvement active system and relative structure, authority and responsibility control, operation process and standards, in order to 
ensure comply with improvement and achieve enterprise active target. In addition, management by patterns of active thinking should carry out communicating harmonization, encourage staffs involvement and full commitment to customer satisfaction, also managers' decision-making should comply with the quality active and target as the maximum guidance principle.

\section{Active Improvement Management by Patterns of Active Thinking}

Active management as a pattern or an improvement that integrates the objectives, policies, and action sequences of an organization into a cohesive whole if well formulated, it can be useful in allocation of an organization's resources into a unique and viable posture based on its relative internal competencies and shortcomings, predicted environmental changes, and intelligent rivals' contingent moves. Active management as the large-scale and future-oriented improvements for interaction with the competitive environment to optimize achievement of an organization's objectives, in other words, a game improvement that although does not detail all of the future needs associated with people, finances, or materials, it provides a framework for decision-making. Management by patterns of active thinking must provide all required resources, according to the improvement then produce and sell products to commitment organization. After the adjustment and improvement, management by patterns of active thinking should re-measure customer expectations, to ensure the improvement scheme is proper and effective.

Active management with the determination of an organization's major and long-term goals, can select of actions, and allocation of the required resources for achieving the goals.

If managers who need less work experience to reach their current hierarchical position are, also those with higher innate abilities the marginal return from one year of active management tenure should decrease with the age of the manager. The marginal return of active management tenure decreases with the age of the manager, but cannot rule out the alternative eximprovementation that investment in on the active management training, as managers get older. The evidence suggests that better assignment of managers to active management positions because of commitment competes with incentive/tournament reasons for explaining the promotion of managers to higher-level active management, something that often ignored in previous empirical tests of tournament models (Eriksson, 1999, 81; Conyon et al., 2001, 301). Implementing good environmental and social practices is good active can give management by patterns of active thinking a competitive advantage and help foster goodwill toward management by patterns of active thinking al active. Management by patterns of active thinking should discuss ways in which management by patterns of active thinking al active honors ethical values and respects people, management by patterns of active thinkingal community, and the environment. Active improvement management by patterns of active thinking and target management structure derive management system requirements in active improvement management. Management by patterns of active thinking should set up definite policy and target and the degree of customer satisfaction should clarify. According to quality target, enterprises should improvement total management system structure, authority and responsibility control, operation process, in order to ensure comply with improvement and achieve enterprise quality target. Management by patterns of active 
thinking should carry out communicating harmonization, encourage staffs involvement and full commitment to customer satisfaction managers' decision-making should comply with the active policy and target as the maximum guidance principle. Management by patterns of active thinking s provide all required resources, according to the improvement then produce and sell products to commitment organization. Active management feedbacks as management by patterns of active thinking aim at commitment organization after sales feedback must verify the degree of customer satisfaction. If it does not achieve the expected degree of satisfaction, the manager should identify the cause and work out an improvement scheme to enhance customer satisfaction. Rectification and preventing methods can used through adjusting original quality policy and target, quality rules, communication, training, resources and operation process, etc. After the adjustment and improvement, enterprises should re-measure customer satisfaction, to ensure the improvement scheme is proper and effective. Management by patterns of active thinking should provide commitment organization' feedback information to management for inspection and verify appropriateness and effectiveness of the definition of quality policy and target, quality scheme and operation methods. The empirical results that the assignment of a manager to particular active management reveals the information employers have about the active management hidden ability at the time of the assignment. The fact that commitment continues after the assignment suggests that the assignment made with imperfect information. If promotions based on the estimated active management ability of the individual managers, workers assigned to a given hierarchical level at the same moment in time will have similar expected abilities, albeit assessed with different levels of precision. Relevant certifications, such as fair-trade certification, organic certification, or leadership in energy and environmental design certification. Environmental programs and resources could influence management by patterns of active thinking al active, from greening your active to finding funding to become environmentally efficient. In order to stay competitive in today's market, management by patterns of active thinking might want to consider where corporate social responsibility fits into your operations. There is no consensus upon the sense of innovativeness. This concept defined as creation of novelty, approach of a behavior or belief that is novel for the organization. A number of the researchers (Kleinschmidt \& Cooper, 1991; Olsen \& Sallis 2006; Olson, Walker, \& Ruekert, 1995) describe innovativeness as degree of novelty that is in connection with corporate and outside world. Although introducing a active management is necessary, it is not sufficient for starting innovation. The innovative product or service should outrival the competitors in the market (Tajeddini, 2010). Management by patterns of active thinking have witnessed what has happened to manufacturers that allowed the quality of their products and services to deteriorate. They also recognize that providing high-quality products and services to keep a customer is much less expensive than acquiring a new one. Products and services quality has a major effect on the ability to attract and retain both commitment organization and employees, and it contributes directly to superior productivity. For this reason, implementing good environmental and social practices is good active can give management by patterns of active thinking a competitive advantage and help foster goodwill toward management by patterns of active thinking al active. Management by patterns of active thinking should discuss ways in which management by patterns of active thinking al 
active honors ethical values and respects people, management by patterns of active thinking al community, and the environment.

\section{Conclusions}

If active management experience and formal education improve the precision of the assessment, then within active management active dispersion should decrease with experience and education, whereas between actives management dispersion expected to increase with these two variables. This distinction, new in the literature formalized and empirically supported by a large sample of data for managerial active. Management by patterns of active thinking competes with the quality level of their products and services, which cannot manage management by patterns of active thinking s competition, will have problems surviving. Active management regarded as one of the prerequisites of success and survival of the active organizations and classified into active improvement and active management in economy and business. The empirical prediction coming from this is that within-active management active dispersion will be lower among that active management for whom the assessment of their ability was more imprecise at the time of the promotion. In order to be able to do this successfully, the products and services management by patterns of active thinking has to view its active and its customer relationships from a products and services quality improvement perspective. There are always relationships between a products and services and its commitment organization expectations. The key issue is whether the firm wants to make use of these relationships in the way it manages commitment organization expectations or not, and whether a given commitment organization wants to be an actively managed relationship with the products and services provider, or not. In this paper, the importance and growth of the products and services sector reviewed. The products and services are expanding globally. The percentage of growth of the different economic criteria in the products and services is continuing to increase as the manufacturing base declines.

Therefore, improving quality is becoming a major objective in management by patterns of active thinking s throughout the world. The recognition that survival much less growth in the rapidly changing market is a function of quality led to the increasing emphasis on active management. Therefore, design management in the products and services is becoming increasingly important and this importance will continue to grow over this century. Improving quality are facing fundamental issues such as how to design and implement an effective quality service delivery system, which will help to establish and to retain global market share. Much of the published work on quality focuses on manufactured products and services, but managers are paying more attention to emphasizing quality in services. The reason is the general perception that products and services quality is not good.

\section{References}

Ashmos, D. P., \& Duchon, D. (2000). Spirituality at work: definitions, measures, assumptions, and validity clamims. Paper presented at the academy of management, Toronto.

Aswad, A. (1989). Quality function deployment: a systems approach. In Proceedings of the 1989 IIE integrated systems conference (pp. 27-32). Norcross, GA.

Auriol, E., \& F. Guido Pechlivanos. (2002). Career Concerns in Teams. Journal of Labor 
Economics, 20. http://dx.doi.org/10.1086/338240

Baker, G., Gibbs, B. Holmstrom. (1994). The Wage Policy of a Management by patterns of active thinking. The Quarterly Journal of Economics, 92.

Barkham, R. (1996). The Determinants of small Management by patterns of active thinking Growth. London, Jessica Kingsley.

Baron, R. M., \& Kenny, D. A. (1986). The distinction in social research. Journal of Personality and Social Psychology, 51.

Barringer Bruce, R. \& Bluedorn Allen, C. (1999). The Relationship Between Corporate Management by patterns of active thinking al active and Strategic Management. Strategic Management Journal, 20, 421-444.

Bauer, T. K., \& Haisken-DeNew J. P (2001). Employer Commitment. Labour Economics, 8. Baysinger, B. D., Kosnik, R., \& Turk, T. A. (1991). Effects ownership structure. Academy of Management Journal, 34. http://dx.doi.org/10.2307/256308

Becker, G. S. (1964). Human Capital. New York: Columbia University Press.

Belsey, D. A., Kuh, A., \& Welsch, M. E. (1980). Regression Diagnostics. New York: John Wiley. http://dx.doi.org/10.1002/0471725153

Bernhardt, D. (1995). Strategic Promotion and Active. Review of Economic Studies, 62. http://dx.doi.org/10.2307/2297807

Bethel, J. E., \& Liebeskind, J. (1993). The effects of corporate ownership on corporate. Strategic Management Journal, 14. http://dx.doi.org/10.1002/smj.4250140904

Blaug, M. (1976). The Empirical Status of Human Capital Theory. Journal of Economic Literature, 14.

Blaug, M. (1992). The Economic Value of Education. Edward Elgar Publishing Limited.

Bolton, B., \& Thompson, J. (2003). Entrepreneurs and Technique. London: Butterworth Heinemann.

Bridge, S., O’Neill, K., \& Cormier, S. (2002). Understanding Enterprise. London: Macmillan Active.

Brunett , Ken. (2001). The Handbook of Key Customer Relationship Management. Prentice Hall.

Bygrave, W. The Portable MBA in Management by patterns of active thinking al active. N.Y: John Wiley and Sons.

C. Temponi, J. Yen \& Tlao, W. A. (1999). House of quality: a fuzzy logic-based requirements analysis. European Journal of Operational Research, 117(2), 340-354. http://dx.doi.org/10.1016/S0377-2217(98)00275-6

Cameron Kim, S. (1996). A study of management by patterns of active thinking al effectiveness and its predictors. Management science review.

Cameron, K. S. (1994). Strategies for successful management by patterns of active thinking al downsizing. Human Resource Management, 33.

Cappelli, P., \& Cascio, W. F. (1991). Why Some Jobs Command Wage Premiums. Academy of Management Journal, 34. http://dx.doi.org/10.2307/256392 
Capron, L. (1999). The long term performance of horizontal commitment. Strategic Management Journal, 20. http://dx.doi.org/10.1002/(SICI)1097-0266(199911)20:11<987::AID-SMJ61>3.0.CO;2-B

Chan and Wu. (2002). Quality function deployment. European Journal of Operational Research, 153. http://dx.doi.org/10.1016/S0377-2217(02)00178-9

Chan and Wu. (2005). A systematic approach to quality function deployment. Omega, 33. http://dx.doi.org/10.1016/j.omega.2004.03.010

Chan et al. (1999). Customer needs in quality function deployment by fuzzy. Journal of Production, 37. http://dx.doi.org/10.1080/002075499190635

Chan, L. K., \& Wu, M. L. (2002). Quality function deployment: A literature review. European Journal of Operational Research, 143, 463-497. http://dx.doi.org/10.1016/S0377-2217(02)00178-9

Chan, L. K., \& Wu, M. L. (2005). A systematic approach to quality function deployment with a full illustrative example. Omega, 33(2), 119-139. http://dx.doi.org/10.1016/j.omega.2004.03.010

Chan, L. K., Kao, H. P., Ng, A., \& Wu, M. L. (1999). Rating the importance of customer needs in quality function deployment by fuzzy and entropy methods. International Journal of Production Research, 37 (11), 2499-2518. http://dx.doi.org/10.1080/002075499190635

Chandler Alfred Jr. (1992). Management and structure. Cambridge mass, M.I.T press.

Chen, L. H., \& Weng, M. C. (2006). An evaluation approach to management design in QFD processes using fuzzy goal programming models. European Journal of Operational Research, 172(1), 230-248. http://dx.doi.org/10.1016/j.ejor.2004.10.004

Chevalier, J., \& Ellison, G. (1999). Career Concerns of Mutual Fund Managers. The Quarterly Journal of Economics, 114. http://dx.doi.org/10.1162/003355399556034

Cohen, L. (1995). Quality function deployment: How to make QFD work for you. Massachusetts: Addison-Wesley.

Cohen, L. (1999). Quality function deployment. Massachusetts: Addison Wesley.

Colin Carnal Susan. (1988). Management principles policy. ICSA Cambridge.

Collis, D. J. (1998). Creating competitive advantage. Harvard Active Review, 76.

Collis, D. J., \& Montgomery, C. A. (1995). Competing on resources. Harvard Active Review, July-August, 73.

Conyon, M. J., Simon, I. P., \& Graham, V. S. (2001). Corporate Tournaments and Executive Active. Strategic Management Journal, 22. http://dx.doi.org/10.1002/smj.169

Cornwall, J. R., \& Perlman, B. (1990). Corporate management by patterns of active thinking al active. Homewood, IL: 17 Boston-Irv. In. Deakins, D., \& Freel, M. (1998), entrepreneurial commitment and the Growth process in SMEs (pp.144-55).

Curran, J., \& Blackburn, R. (2002). Active improvementning and Local Economic Networks. London: Paul Chapman.

David, F. A. (2000). Strategic management (Translated by A. Parsian and M. Araabi). Tehran: Cultural Researches Office. 
DeGroot, M. H. (1970). Optimal Statistical Decisions. New York: McGraw-Hill.

Denison Daniel R. (1995). Corporate culture and management by patterns of active thinking al effectiveness. New York: John wiles andsons.

Dimitratos, P. et al. (2004). The relationship between management by patterns of active thinking al active and international performance: the importance of domestic environment. International Active Review, 13, 19-41.

Enrahimp-pour, H., Khalili, H., \& Habibian, S. (2011). The investigation of relationship between strategic management and management by patterns of active thinking al active. Management Researches, 11 .

Entrialgo, M. et al. (2000). Linking management by patterns of active thinking al active and strategic management: evidence from Spanish SMEs. Technovation, 20, 427-436. http://dx.doi.org/10.1016/S0166-4972(99)00168-6

Ergün Ercan, et al. (2004). Connecting The Link Between Corporate Management by patterns of active thinking al active And Innovative Performance. Global Active and Technology Association Annual Conference Proceedings Book (pp.259-265). July, Cape Town.

Eriksson, T. (1999). Executive Active and Tournament Theory. Journal of Labor Economics, 17.

Evans and Lindsay. (2002). Management and control of quality. Singapore: Thomson Commitment.

Evans, J. R., \& Lindsay, W. M. (2002). Management and control of quality (5th ed.). Thomson Commitment, Singapore.

Farber, H. S., \& Gibbons, R. (1996). Commitment and Wage Dynamics. The Quarterly Journal of Economics, 111.

Feghhi Farahmand, Nasser. (2001). Executive Management Process (pp. 109-203). Islamic Azad University, Tabriz Branch, Iran.

Feghhi Farahmand, Nasser. (2003). Permanent Management of Management by patterns of active thinking (pp. 70-83). Tabriz, Iran: Frouzesh Publication.

Feghhi Farahmand, Nasser. (2003). Strategic Structure of Management by patterns of active thinking Management Process (4th ed., pp.110-125). Islamic Azad University, Tabriz Branch, Iran.

Feghhi Farahmand, Nasser. (2005). Strategic Management of Management by patterns of active thinking (1st ed., p. 19). Frouzesh Publication, Tabriz, Iran.

Feghhi Farahmand, Nasser. (2009). Management by patterns of active thinking Strategic Improvement compilation (1st ed., pp. 74-314). Tabriz, Iran: Frouzesh Publication.

Feghhi farahmand, Nasser. (2011). Active and Dynamic Management of Management by patterns of active thinking (2nd ed., pp. 87-190). Tabriz, Iran: Frouzesh Publication.

Feghhi Farahmand, Nasser. (2011a). Technology Management of Management by patterns of active thinking (2nd ed., pp. 11-198). Tabriz, Iran: Frouzesh Publication.

FIB. (1998). Uusinta tietoa suomalaisten asenteista biotekniikkaan. FIB, Suomen Bioteollisuus.

Finkelstein, S. (1992). Power in top management teams, measurement and validation. 
Academy of Management Journal, 35.

Foster, A. D., \& Rosenzweig, M. R. (1993). Information Commitment, and Wage Rates in Low-Income. The Journal of Human Resources, 28.

Frewer, L., Rowe, G., Marsh, R., \& Reynolds, C. (2001). Public Participation Methods: Evolving and Operationalising an Evaluation Framework. UK Department of Health.

Fry, L. W. (2003). Toward a theory of spiritual leadership. The Leadership Quarterly, 14, 693-727. http://dx.doi.org/10.1016/j.leaqua.2003.09.001

Fry, L. W., \& Matherly, L. L. (2006). Spiritual Leadership and Management by patterns of active thinking al Performance: An Exploratory Study. Tarleton State University Central Texas.

Fry, L. W., Vittuci, S., \& Cedillo, M. (2005). Spiritual leadership and army transformation: Theory measurement, and establishing a baseline. The Leadership Quarterly, 16, 835-862. http://dx.doi.org/10.1016/j.leaqua.2005.07.012

Fuller, S. (2000). The Governance of Science: Ideology and the Future of the Open Society. Buckingham - Philadelphia: Open University Press.

Fung, et al. (1998). Customer requirement analysis. International Journal of Production, 38. Fung, et al. (2006). Quality function deployment under uncertainties. Fuzzy Systems, 157.

Fung, R. Y. K., Chen, Y. Z., \& Tang, J. F. (2006). Estimating the functional relationships for quality function deployment under uncertainties. Fuzzy Sets and Systems, 157(1), 98-120. http://dx.doi.org/10.1016/j.fss.2005.05.032

Fung, R. Y. K., Popplewell, K., \& Xie, J. (1998). An intelligent hybrid system for customer requirement analysis and product attribute targets determination. International Journal of Production Research, 36(1), 13-34. http://dx.doi.org/10.1080/002075498193912

Garicano, L. (2000). Hierarchies and the Management by patterns of active thinking of Knowledge in Production. Journal of Political Economy, 108.

Garvin, D. A. (1987). Competing on the eight dimensions of quality. Harvard Bus. Rev., 65, 101-109.

Gerhart, B., \& Milkovich, G. (1990). Management by patterns of active thinking al Differences in Managerial Active. Academy of Management Journal, 33.

Gerwin, D. (1993). Manufacturing flexibility strategic perspective. Manage. Sci., 39, 395-410. http://dx.doi.org/10.1287/mnsc.39.4.395

Gibbons, R., \& Murphy, K. (1992). Optimal Incentives Contracts in the Presence of Career Concerns. Journal of Political Economy, 100. http://dx.doi.org/10.1086/261826

Gibbons, R., \& Waldman, M. (1999). A Theory of Wage and Promotion Dynamics. The Quarterly Journal of Economics, 114. http://dx.doi.org/10.1162/003355399556287

Gibbs, P. A. (1993). Determinants of corporate restructuring. Strategic Management Journal, 14. http://dx.doi.org/10.1002/smj.4250140906

Greene, W. H. (1998). Econometric Analysis. Prentice-Hall International Limited.

Greene, W. H. (2000). Econometric Analysis. Cliffs, NJ: Prentice Hall.

Greenwald, B. C. (1986). Adverse Selection in the Labour Market. Review of Economic 
Studies, 53. http://dx.doi.org/10.2307/2297632

Griffin and Hauser. (1993). The voice of the customer. Marketing Science, 12. http://dx.doi.org/10.1287/mksc.12.1.1

Gustafsson, A., \& Gustafsson, N. (1994). Exceeding customer expectations. In Proceedings of the sixth symposium on quality function deployment (pp. 52-57). Novi, MI.

Hamel, G., \& Prahalad, C. K. (1994). Competing for the Future. Harvard Active School, Boston, London.

Harris, M., \& Holmstrom, B. (1982). A Theory of Wage Dynamics. Review of Economic Studies, 49. http://dx.doi.org/10.2307/2297359

Harvey, A. (1976). Estimating Regression Models with Multiplicative Heteroskedasticity. Econometrica, 44. http://dx.doi.org/10.2307/1913974

Haunschild, P. R. (1994). How much is that management by patterns of active thinking worth? Administrative Science Quarterly, 39.

Hauser and Clausing, J. R. (1996). The house of quality. IEEE Management Management Review, 24(1), 24-32.

Hauser, J. R., \& Clausing, D. (1988). The house of quality. Harvard Active Review, 63-73.

Hayes, R., \& Clark, K. (2003). Why some factories are more productive than others. Harvard Active Review.

Haynes, M., Thompson, S., \& Wright, M. (2002). Management by patterns of active thinking performance. The Journal of Industrial Economics, 1 .

Hitt, M. A., Bierman, L., Uhlenbruck, K., \& Shimizu, K. (2006). Resources. Academy of Management Journal, 49.

Ho, E. S., Lai, Y. J., \& Chang, S. I. (1999). An integrated group decision-making approach to quality function deployment. IIE Transactions, 31, 553-567. http://dx.doi.org/10.1080/07408179908969858

Ho, et al. (1999). An integrated group decision making approach to QFD. IIE Transactions, 31. http://dx.doi.org/10.1023/A:1007654407406

Holmstrom, B. (1982). Managerial Incentive Schemes. Reedited in Review of Economic Studies, 66.

Hong, H., \& Kubik, J. D. (2003). Analyzing the Analysts. Journal of Finance, 58. http://dx.doi.org/10.1111/1540-6261.00526

Ireland, R. D., Covin Jeffrey, G., \& Kuratko Donald, F. (2009). Conceptualizing Corporate Management by patterns of active thinking al active Management (pp. 1042-2587). Baylor University, Management by patterns of active thinking al active Theory and Practice.

Irwin, A. (1995). Citizen Science: A Study of People, Expertise and Sustainable Development. London and New York, Routledge.

Irwin, A., \& Wynne, B. (1996). Misunderstanding Science? The Public Reconstruction of Science and Technology (pp. 1-17). Cambridge, Cambridge University Press. http://dx.doi.org/10.1017/CBO9780511563737.001

Jagdish, N. (2001). Customer Relationship Management: Concept, Tools, Applications. 
McGraw Hill.

Johnson, M. D., \& Gustafsson, A. (2000). Improving customer satisfaction. Jossey Bass Press.

Joss, S., \& Durant, J. (1995). Public Participation in Science - The Role of Consensus Conferences in Europe. London, Science Museum with the Support of the European Comapproachs Directorate General XII.

Karsak, E. (2004). Fuzzy multiple objective programming in qfd. Industrial Management, 47. Karsak, E. E. (2004). Fuzzy multiple objective programming framework to prioritize design requirements in quality function deployment. Computers and Industrial Management, 47, 149-163. http://dx.doi.org/10.1016/j.cie.2004.06.001

Karsak, E. E., Sozer, S., \& Alptekin, S. E. (2002). Product improvementing in quality function deployment using a combined analytic network process and goal programming approach. Computers and Industrial Management, 44 (1), 171-190. http://dx.doi.org/10.1016/S0360-8352(02)00191-2

Karsak, et al. (2002). Product improvementning in quality function deployment. Industrial Management, 44.

Kaufmann and Gupta. (1985). Introduction to fuzzy arithmetic Van No strand Reinhold. New York.

Kendall, st., friezes, Ja., \& steeples, Jo, et al. (2004). Flexibility program. Journal of clinical management.

Khanka, S. (2003). Entrepreneurial Development. New Delhi: Chandan Company ltd.

Khoo and Ho, L. P. (1996). Framework of a fuzzy QFD system. International Journal of Production Research, 34.

Khoo, L. P., \& Ho, N. C. (1996). Framework of a fuzzy quality function deployment system. International Journal of Production Research, 34(2), 299-311. http://dx.doi.org/10.1080/00207549608904904

Klüver, L., Nentwich, M., Peissl, W., Torgersen, H., Gloede, F., Hennen, L., Eijndhoven, J. v., Est, R. v., Joss, S., \& Bellucci, S. (2000). European Participatory Technology Assessment. Participatory Methods in Technology Assessment and Technology Decision-Making. Copenhagen, The Danish Board of Technology.

Koratco, D. Of., \& Richard, M. H. (2004). Current view on management by patterns of active thinking al active (Translated by E. A. Mehrabi, and Tabraei, M.). Mashhad: Ferdosi University of Mashhad Publications.

Kotha, Suresh. (2010). spillovers, spill-ins and strategice enterpreneurship: America's first commercial jet airimprovemente and boeing s ascendancy in cimmercial aviatin, Strategic Management by patterns of active thinking al active Journal, 4, 284-306.

Kuwahara, T., (1997). Technology Foresight in Japan: a New Approach in Methodology and Analysis (pp. 87-93). Technology Foresight, NSTDA, Bangkok.

Kwong and Bai, C. K. (2002). A fuzzy AHP approach in QFD. Journal of Manufacturing, 13. Kwong, C. K., \& Bai, H. (2002). A fuzzy AHP approach to the determination of importance weights of customer requirements in quality function deployment. Journal of Intelligent 
Manufacturing, 13(5), 367-377. http://dx.doi.org/10.1023/A:1019984626631

Lai et al., Lai, Y. J., Ho, E. S., \& Chang, S. I. (1998). Identifying customer preferences. Wiley, NY.

Lazear, E., \& Rosen, S. (1981). Rank Order Tournaments as Optimum Labour Contracts. Journal of Political Economy, 89. http://dx.doi.org/10.1086/261010

Leonard, D. (1997). Spark innovation through empathic design. Harvard Active Rev., 75, 102-113.

Leonard, J. (1990). Executive Pay and Management by patterns of active thinking Performance. Industrial and Labour Relations Review, 43.

Martin, B. R. (1997). Technology Foresight as a Tool for Strategic Management. In Ch. 2, Anderson, J., Fears, R., \& Taylor, B. (Eds.), Managing Technology for Competitive Advantage (pp. 131-147). Financial Times Healthcare, London.

Mason, C., \& Stark, M. (2004). What do Investors look for in a Active Improvement. International Active Journal, 32.

McKinley, W., Zhao, J., \& Rust, K. G. (2000). A socio cognitive interpretation. Academy of Management Review, 25.

Michael, M. (2001). Technoscientific Bespoking: Animals, Publics and the New Genetics. New Genetics and Society, 20(3), 205-224. http://dx.doi.org/10.1080/14636770120092985

Miettinen, R., \& Väliverronen, E. (1999). In Science and Technology We Trust: On the Public Understanding of Science in Finland. Biotechnology and Public Understanding of Science. Proceedings of the UK-Nordic Co-Operative Seminar Helsinki October 25-27, 1998 Publications of the Academy of Finland 3/99.

Mincer, J. (1974). Schooling, Experience, and Earnings. New York, Columbia University.

Morgan R. (1994). The Emergence of new management by patterns of active thinking al forms. London, no 27.

Morrow, J. L., Sirmon, D. G., Hitt, M. A., \& Holcomb, T. R. (2005). Creating Value. Society Conference, Orlando.

Murphy, K. J. (1986). Incentives, Commitment, and Active. Journal of Economics, 17.

Niva, M. (2002). Gene Technology in Food Production and Consumer Interpretations of Risks.

Nixon, R. D., Hitt, M. A., Lee, H., \& Jeong, E. (2004). Market reactions. Strategic Management Journal, 25.

Novos, I. E. (1992). Commitment by Doing, Adverse Selection, and Management by patterns of active thinking Structure. Journal of Economic Behavior and Management, 19. http://dx.doi.org/10.1016/0167-2681(92)90068-M

NSTDA. (1996). Important Future Technologies of Thailand. An Active Undertaken by Chiang Mai University, NSTDA, Bangkok.

Ortín-Angel, P., \& Salas-Fumas, V. (1998). Agency Theory and Internal Labor. Journal of Economics and Management, 7.

Ortín-Angel, P., \& Salas-Fumas, V. (2002). Active and Span of Control in Hierarchical 
Management by patterns of active thinking s. Journal of Labor Economics, 20.

Poppo, L., \& Weigelt, K. (2000). A Test of the Resource-Based Model Using. Journal of Economics and Management Management, 9.

Porter, M. E. (1985). Competitive Advantage (1st ed.). New York: Free Press.

Robert, K., \& David, N. (1992). The balanced scorecar measures that drive performance. Harvard Active Rev., 70, 71-79.

Robertshaw, W. (1995). Using an objective sales point measure to incorporate elements of the Kano model into QFD. Transactions from the 7th Symposium on QFD (pp. 201-216).

Rosen, S. (1986). Prizes and Incentives in Elimination Tournaments. American Economic Review, 76.

Rue, L., \& Ibrahim, N. (1998). Improvementning and Performance. Journal of small Active Management, 36.

Runkler, T. A. (1997). Selection of appropriate defuzzification methods using application specific properties. IEEE Transactions on Fuzzy Systems, 5(1), 72-79. http://dx.doi.org/10.1109/91.554449

Runkler, T., \& Runkler. A. (1997). Selection of appropriate defuzzification methods. IEEE Fuzzy Systems, 5. http://dx.doi.org/10.1109/91.554449

Salop, J., \& Salop, S. (1976). Self-Selection and Turnover in the Labor Market. The Quarterly Journal of Economics, 90. http://dx.doi.org/10.2307/1885325

Sattinger, M. (1975). Comparative Advantage and the Distribution of Earnings. Journal of Economic Literature, 43.

Schwenk, C. R., \& Shrader, C. B. (1993). Effects of formal Strategic Improvementning. Theory and Practice, 17.

Seth, A., Song, K. P., \& Pettit, R. R. (2002). Value creation and destruction. Strategic Management Journal, 23.

Shemwell, D. (1998). Practices for Sales Culture. International Journal of Marketing, 16(7).

Shen, X., Tan, X., \& Xie, M. (2001). QFD on linguistic data. Journal of Manufacturing, 12. http://dx.doi.org/10.1023/A:1008955630880

Solvency Gavial. (1992). Handbook of industrial Management. John wily andsons Inc.

Spence, M. (1976). Competition in Salaries, Credentials for Jobs. The Quarterly Journal of Economics, 90. http://dx.doi.org/10.2307/1886086

Stalk, G. (1988). Time the next source of competitive advantage. Harvard Bus. Rev., 66, 41-51.

Stutely, R. (2003). The definitive Active Improvement. London: Financial Times Prentice Hall. Sullivan, L. P. (1986). Quality function deployment. Quality Progress, 19, 39-50.

Sullivan, L. P. (1999). QFD, Quality Progress.

Tempon, et al. (1999). House of quality. European Journal of Operational Research, 117. http://dx.doi.org/10.1016/S0377-2217(98)00275-6

Thompson, J. D. (2004). Management by patterns of active thinking s in action. New York: Mc Graw Hill. 


\section{Macrothink Institute ${ }^{\mathrm{m}}$}

Tieh-Min Yen, Yi-Chan Chung \& Chih-Hung Tsai (2000). Active Opportunity Algorithm for ISO 9001: 2000 Customer Satisfaction Management Structure. Retrieved from http://scialert.net/fulltext/?doi=rjbm.2007.1.10andorg=10

Tieh-Min Yen, Yi-Chan Chung \& Chih-Hung Tsai. (2007). Active Opportunity Algorithm for ISO 9001: 2000 Customer Satisfaction Management Structure. Retrieved from http://scialert.net/fulltext/?doi=rjbm.2007.1.10andorg=10

Topel, R. (1991). Specific Capital, Mobility, and Wages. Journal of Political Economy, 99. http://dx.doi.org/10.1086/261744

Ullmand, D. G. (1992). The mechanical design process. New York: McGraw-Hill.

Ullmand, D.G. (1992). The mechanical design process. New York: McGraw Hill.

Ulwick, A.W. (2002). Turn customer input into innovation. Harvard Active Rev., 80, 91-97.

Vaara, E., Tienari, J., \& Piekkari, R. (2005). Circuits of power in corporation. Journal of Management Studies, 42. http://dx.doi.org/10.1111/j.1467-6486.2005.00510.x

Vanegas and Labib. (2001). A fuzzy QFD model. International, Journal of Production, 39.

Vanegas, L. V., \& Labib, A. W. (2001). A fuzzy quality function deployment (FQFD) model for driving optimum targets. International Journal of Production research, 39(1), 99-120. http://dx.doi.org/10.1080/00207540010005079

Waldman, M. (1984). Job Assignments, Signaling and Efficiency. Journal of Economics, 25.

Waldman, M. (1990). Up-or-out Contracts: A Signaling Perspective. Journal of Labor Economics, 8. http://dx.doi.org/10.1086/298221

Wang, J. (1999). Fuzzy outranking approach to prioritize design requirements in quality function deployment. International Journal of Production Research, 37(4), 899-916. http://dx.doi.org/10.1080/002075499191599

Xie, M., Goh, T. N., \& Wang, H. (1998). A study of the sensitivity of customer voice in QFD analysis. International Journal of Industrial Management, 5(4), 301-307.

Xie, M., Tan, K. C., \& Goh, T. N. (2003). Advanced QFD applications. Milwaukee, Wisconsin: ASQ Quality Press.

Zairi, M., \& Youssef, M. A. (1995). Quality function deployment: a main pillar for successful total quality management and product development. International Journal of Quality and Reliability Management, 12(6), 9-23. http://dx.doi.org/10.1108/02656719510089894

Zhao, R. H., \& Govind, R. (1991). Defuzzification of fuzzy intervals. Fuzzy Sets and Systems, 43, 45-55. http://dx.doi.org/10.1016/0165-0114(91)90020-Q

Zhou, M. (1998). Fuzzy logic and optimization models for implementing QFD. Computers and Industrial Management, 35(1-2), 237-240. http://dx.doi.org/10.1016/S0360-8352(98)00073-4 http://www.canadaactive.ca/eng/125/141/ http://www.canadaactive.ca/eng/145/146/

http://www.canadaactive.ca/eng/86/

http://www.canadaactive.ca/eng/87/187/ 


\section{Macrothink

\section{Copyright Disclaimer}

Copyright reserved by the author(s).

This article is an open-access article distributed under the terms and conditions of the Creative Commons Attribution license (http://creativecommons.org/licenses/by/3.0/). 